\title{
EXAMINING RESIDENT'S PERCEPTION OF SUSTAINABILITY TOURISM PLANNING AND DEVELOPMENT: THE CASE OF MALANG CITY, INDONESIA
}

\author{
Andy KURNIAWAN \\ Brawijaya University, Faculty of Administrative Science, MT. Haryono, Malang, Indonesia, e-mail: andy_fia@ub.ac.id \\ Dahlan FANANI \\ Brawijaya University, Faculty of Administrative Science, MT. Haryono, Malang, Indonesia, e-mail: dahlan_fia@ub.ac.id \\ SUPRIONO* \\ Brawijaya University, Faculty of Administrative Science, MT. Haryono, Malang, Indonesia, e-mail: supriono_fia@ub.ac.id
}

\begin{abstract}
Citation: Kurniawan, A., Fanani, D., \& SUPRIONO. (2022). EXAMINING RESIDENT'S PERCEPTION OF SUSTAINABILITY TOURISM PLANNING AND DEVELOPMENT: THE CASE OF MALANG CITY, INDONESIA. GeoJournal of Tourism and Geosites, 40(1), 242-252. https://doi.org/10.30892/gtg.40129-825
\end{abstract}

\begin{abstract}
Tourism development includes many studies on how planning and community views view the impact of tourism. This study presents the concept of tourism development that focuses on local people's perceptions of the impact of tourism. This study explores and explains the role of applied planning that affects the impact generated by tourism. The variables used in this study are key factors in supporting tourism development. This study uses a quantitative approach through statistical analysis of PLS-SEM and the distribution of a questionnaire that has been designed to 200 local communities. The sampling technique of this study used purposive sampling on local communities in tourist sites in Malang City. The findings show that optimal planning will support institutional stability which also has an impact on the perceived impact. This study contributes to broadening knowledge about the perceived impact of tourism by adding planning and stability aspects that are used to assess support for tourism development.
\end{abstract}

Key words: Tourism Planning, Institutional Stability, Perceived Tourism Impact, Tourism Development

$* \quad * \quad * \quad * \quad * \quad *$

\section{INTRODUCTION}

The tourism sustainability has been known as one of the most interesting topics to discuss. Developments related to this topic are very fast due to technological developments and changes in environmental conditions as well as various benefits generated. Lemy et al., (2019) identifies three main objectives of sustainable tourism (1) to meet the needs of local communities to improve their standard of living, both in the short and long term; (2) to meet tourist demand; and (3) protecting the natural environment to achieve the previous two objectives. Even so, every tourism must have an impact which is an interesting topic to discuss. The growing interest in this topic is because tourism is considered to have various positive effects (Zeng et al., 2020; Andereck and Nyaupane, 2011; Diedrich and Garcia, 2009; Andereck et al., 2005) and negative effects (Prayag et al., 2013; Nunkoo and Gursoy, 2012; Vargas-Sanchez et al, 2011). The impact is felt by all parties involved in tourism such as residents or communities (Almeida et al., 2016; Andereck and Nyaupane, 2010; Oviedo-Garcia et al., 2008; Yoon et al., 2001), government (Siakwah et al., 2019; Bichler, 2019; Jamal and Camargo, 2018) and tourists (Hayati et al., 2020; Zhang et al., 2019; Neuts and Nijkam, 2012; Petrosillo et al., 2006).

Various studies have discussed predictors or antecedents from various perspectives of the impacts caused by tourism, which include economic, environmental, and socio-cultural. The positive impacts of tourism, among others, are that tourism is able to create new jobs for local residents, improve the economic standard of the community and become one of the supporters of state income by strengthening business networks, improving the quality of life of residents, helping to preserve local culture and related sites. Even so, the negative impacts caused by tourism cannot be avoided. This makes the negative attitude of tourism stakeholders grow. However, proactive and positive behavior in terms of stakeholder attitudes towards sustainable tourism development is very influential in minimizing losses due to tourism. Therefore, a careful planning is needed to support sustainable tourism. The importance of planning is evidenced by the important role that planning aspects have which are considered as a tool for integrating tourism and other sectors, controlling development patterns, protecting and conserving resources and even providing a framework for further tourism development. Hall (2008) suggests that the key to the success of sustainable tourism development is optimal collaboration of all stakeholders in tourism. Although each stakeholder group has different responsibilities and reasons, cooperation between them is necessary for supply and demand balance, tourism impact management, and resource allocation (Bregoli, 2012).

Through collaborative planning, the goals and objectives of the tourism development management plan become more integrated (Jamal and Stronza, 2009). Policy decisions related to optimal sustainable tourism should reflect the views of each stakeholder as a reflection of their participation in sustainable tourism (Bramwell, 2010). In addition, several studies have

\footnotetext{
* Corresponding author
} 
shown that collaborative tourism planning is more effective than other types of tourism planning (Harril, 2004). Based on this, this study emphasizes that the planning function is very important in tourism development because it involves exchanges between stakeholders to be able to produce benefits. As in several similar studies discussing tourism planning to develop and review an integrated theoretical framework that has socially responsible goals (d'Angella and Go, 2009; Su et al., 2018; Su et al., 2016; Theodoulidis et al., 2017). Meanwhile, the tourism sector in Indonesia still needs to be developed further because it refers to T\&T Indonesia had been declared the third largest economy after Thailand and the Philippines (Wilopo et al., 2020). Nevertheless, tourism development is still being encouraged to encourage national economic growth. Even so, tourism development planning is often seen as an action that is only carried out by the government so that input from the majority of the community or the non-tourism sector is not paid attention to (Moscardo, 2011). In line with this, several recent discussions show that the planning process in Malang City is also still centered on the local government so that it has not yet received optimal acceptance in practice. So there is still a need for further exploration of the practice and effectiveness of public participation in tourism planning. So far, the active participation of other parties is reflected in tourism development, such as participating in promoting and maintaining tourism objects in Malang City (Pramono et al., 2021). Discussions related to participatory planning to date have largely neglected to examine how participation and tourism planning affect the impact of tourism and the development of sustainable tourism. The current discussion requires a more critical understanding of how collaborative planning practices process. Therefore, the objectives of this study are threefold: (1) to provide a theoretical explanation of tourism planning and public participation in Malang City; (2) Assessing various impacts caused by tourism in Malang City; and (3) to discuss more broadly the factors that can influence tourism development in Malang City.

\section{LITERATURE REVIEW}

\section{Stakeholder Theory}

A set of ideas or ideas that aim to control human activities over time is known as planning (Hall, 2008). Stakeholder theory has been adopted in several studies related to tourism policy and planning (Su et al., 2018; Theodoulidis et al., 2017; Lee and Hsieh, 2016; d'Angella and Go, 2009). Stakeholder theory actually discusses how from a "managerial" point of view to perform tasks, and is closely related to business practices, value creation and trade (Laplume et al., 2008). In addition, stakeholders through relevant policies can manage destinations that can provide social impacts to the surrounding community and sustainable development in the tourism sector (Byrd et al., 2009). In this context, stakeholders who have an important role in tourism development and planning can generate benefits. The benefits derived and the reduction in costs can lead to residents' satisfaction with tourism and community development (Vargas-Sa'nchezet al., 2009; Vargas-Sa'nchez et al., 2011). According to stakeholder theory, all stakeholder groups should be involved in the whole process of tourism development (Goeldner and Ritchie, 2009), and the sustainability of tourism development is determined by stakeholder perspectives, for example, by involving residents, tourism entrepreneurs, government, and tourists (Lynch et al., 2011; Hallak et al., 2012). Several studies state that tourism planning was born out of the need to grow new business opportunities (Bianchi, 2018; Lohmann and Netto, 2016). Sustainable tourism certainly requires awareness of tourism activities that have a relatively low impact so that effective planning is needed. With planning, stakeholders can maximize benefits and minimize losses due to tourism for the community, government, environment and tourists (Ampong, 2018).

In the view of tourism, planning can be used as a key process to maximize the long-term benefits of tourism (Bianchi, 2018). The strength of the tourism business can be built as a regional or national strength. Long-term regulation is important because market or environmental conditions are inherently unstable and require a planning basis to measure the success rate of tourism in a sustainable manner (Wang and Bramwell, 2012). Faced with this strong economic outlook, the role of government in encouraging the development of tourism planners is not short-lived (Telfer and Sharpley, 2015). Planning is carried out by considering all activities that affect the sustainability of all aspects of tourism in the long term. Lack of precise long-term planning is often associated with ineffective formulation processes carried out by government institutions. The government certainly needs to maintain political legitimacy in the context of social relations in the implementation of tourism because without this stability the government can fail to maintain the necessary authority to regulate the economy and maintain social order which of course affects tourism activities (Adinolfi, 2019).

\section{H1: Long-term planning has a positive effect on institutional sustainability}

According to stakeholder theory, many stakeholders are involved in tourism including planning activities such as governments, local residents, non-governmental organizations (NGOs), non-profit organizations, and other tourism-related businesses. The collaborative approach to tourism planning focuses on the role of each stakeholder in planning. According to stakeholder theory, all stakeholder groups should be involved in the entire tourism development process (Goeldner and Ritchie, 2009). Such as recommendation by Buhalis and Amaranggana (2013) had suggested that there are six measures that need to be achieved for the success of tourism development, such as attractions, accessibility, facilities, available services, available activities, and supporting services. Each stakeholder must participate actively in all stages of planning development and implementation. Thus, the community can help with proper planning by ensuring that all participants are involved in the planning process so that the government can consider the role of the community in tourism. However, the implementation of tourism planning is currently centralized to the government with a minimum level of involvement of other stakeholders. These pressures support the need to review the participation of all stakeholders in tourism planning (Forester, 2000). Studies reveal that self-interest and lack of trust among stakeholders can frustrate many tourism planning and collaborative efforts (Serravalle et al., 2019; Saito and Ruhanen, 2017; Waligo et al., 2013; Byrd et al., 2009). This certainly has an impact on institutional sustainability because the plans formulated by the local government are less effective. 
H2: Political Participation has a positive effect on institutional sustainability

Tourism planning certainly needs to pay attention to all existing aspects so that planning is prepared based on these aspects. This is because the development of tourism potential aims to increase the resources owned by a tourist destination in the form of physical and non-physical elements. Tourism planning and development itself is part of the political process related to the formulation of policies or decisions to achieve certain goals (Veal, 2002). Thus, the formulation of tourism development policies and the preparation of optimal structural plans must be integrated so as to create an appropriate policy (Tkaczynski et al., 2009). Tourism policy in Indonesia refers to the relationship between industry and the implementation of organizational functions. These policies can be in the form of laws, regulations and appeals with the aim of influencing the tourism industry, either directly or indirectly. Policies that exist in one area and another are certainly different. Kaiser and Helber (1978) explain that the levels of tourism planning start from the development of regional tourism or regional tourism or local planning. Local level planning is needed because it relates to various efforts to empower, develop, and manage all aspects of tourism in the City. At the local level, various interests of local communities, operators, tourists, local government authorities meet to create interactions with each other. The relationship between the tourism industry is also shown by the linkage of tourism services with other sectors such as forestry, urban areas, education, and infrastructure (Pforr, 2006). Inability to communicate, coordinate or differ in understanding of tourism planning is usually found. This can lead to uncertainty about the limits of authority, rights and obligations. As a result, it often creates problems or conflicts. This situation can threaten the success of tourism planning. Therefore, local planning policy also plays a role in institutional sustainability.

H3: Local planning policy has a positive effect on institutional sustainability

\section{Institutional Sustainability}

In a general sense, governance refers to all patterns of power, authority and rules that can secure order, and it is relevant to situations where there is a hierarchical state, where the state is dependent on others, or where the state plays little or no role (Bramwell, 2011). Thus, one of the dimensions that influence tourism development is institutional sustainability (Ko, 2001). This dimension is the result of the interaction process inherent in the mode of governance (Lange et al., 2013). Ross and Wall (1999) also established a framework for sustainable tourism development that emphasizes the assessment of political and governance stability that can be affected by the relationship between local communities, tourism and resources. Given the many actors involved in tourism development, the concept of institutional strength in an area must be considered (Dabphet et al., 2012). Institutional agents are considered to play an important role in the creation and development of sustainable tourism. The number of initiatives and institutional policies developed affect the success of a tourism development. Several studies reveal that the key to implementing sustainable tourism lies in its practical application so that it depends on the skills of stakeholders governed by the government (Bianchi, 2004; Dodds, 2007; Waligo et al., 2013). Therefore, the institutional initiatives that emerge from development and tourism policies have a decisive role in the creation and acceptance of the concept of sustainable tourism. Sofield (2003) found that government stability such as decision-making processes, and optimal policy-making can affect tourism development. The successful implementation of sustainable tourism is highly dependent on the government's ability to coordinate and balance the roles and interests of stakeholder groups and to protect resources through appropriate development strategies. Institutional policies and initiatives have gradually evolved from the initial acceptance of sustainability in tourism as linked almost exclusively to environmental conservation, to a more global concept that takes into account the balance between people, the environment and the economy. Tourism itself is a multifaceted phenomenon that certainly has an impact on various aspects of the destination and its community. Therefore, institutional sustainability is one of the factors that influence the impact of tourism. Policies that are made can have a positive or negative impact on other stakeholders related to tourism activities. Scheyvens (2011) argues that it is the government that has the stable power to set policies that affect the utilization of economic benefits from local communities and the preservation of social, cultural and environmental resources.

H4: Institutional sustainability has a positive effect on the perceived economic impact

H5: Institutional sustainability has a positive effect on the perceived environmental impact

H6: Institutional sustainability has a positive effect on the perceived socio-cultural impact

\section{Impact of Tourism}

Understanding how stakeholders view tourism impacts helps to better understand how tourism currently benefits the many parties involved (Perskins et al., 2020; Wondirad et al., 2020). Thus, it is logical to examine their perceptions of the impact of tourism so that factors that contribute to positive attitudes related to tourism development can be found. Policy makers in the context of tourism often focus on stimulating tourism by providing the essential conditions for tourism growth (Minnaert, 2020), so tourism often has a significant impact on the economy, the environment, as well as social and cultural structures and dynamics (Rogerson and Rogerson, 2019). One of the easiest impacts to measure is the economy, studies conclude that the economic impact of tourism development is mostly viewed positively by the community (Gursoy et al., 2009). This is because tourism is an economic development tool because it provides employment opportunities so that it is considered able to improve the economy of the surrounding population (Choi and Sirakaya, 2005). The positive economic impact mainly comes from direct income, employment for the tourism industry, foreign exchange earnings, increased public and private investment and additional personal income. Meanwhile, the negative economic impact is reflected mainly in inflation and rising cost of living. The socio-cultural impact generated by tourism is considered less. Even so, the social impact of tourism development can be reflected in the improvement of the quality of life of the 
population (Adinolfi, 2019; Andereck and Vogt, 2000). Positively, tourism development can lead to improved community services so as to enhance local cultural identity and the welfare of the population as a whole. However, negatively tourism also causes an increase in crime rates, moral degradation, cultural exploitation, overcrowding and overuse of resources along with tourism development. Meanwhile, environmental impacts are complex and specific to the environment. While tourism revenues can enhance existing attractions, the adverse environmental impacts are mainly seen in tourist flows such as natural feel, pollution and congestion. Even so, the type and magnitude of the impact caused by tourism is not easy to measure. This is because the extent to which tourism has contributed to the economic, social or environmental problems of an area is often not known with certainty (Mathieson and Wall, 1982). Lastly, the fact that different destinations experience different impacts or even the same impacts but with different degrees/stages, adds to the difficulty in understanding the impacts brought about by tourism. In this study, social exchange theory is used as a basis for discussing the perceptions of residents about the impact of tourism and their support for tourism development in the region. This theory has been used in several studies related to population perceptions (Adongo et al., 2019; Kang and Lee, 2018; Nunkoo, 2016; Ward and Berno, 2011). According to this theory, by suggesting the positive impact of tourism, stakeholders will tend to support tourism development because it is considered profitable. However, tourism does not only have a beneficial impact, there are also negative effects that arise. This of course creates a negative perception of stakeholders such as local communities related to tourism. This is important to note because the positive attitude and perception of residents is very important to encourage visitor satisfaction. By using social exchange theory, residents' perceptions can be well identified as valuable or not for tourism development. Therefore, there is a need for a comprehensive study that concentrates on people's perceptions of tourism development.

H7: Perceived economic impact has a positive effect on tourism development

H8: Perceived environmental impact has a positive effect on tourism development

H9: Perceived social cultural impact has a positive effect on tourism development

\section{Tourism Development}

Social Exchange Theory is considered to have contributed a lot in understanding public perceptions of the impact of tourism (Fredline and Faulkner, 2000). It is important to understand people's perceptions of the impact of tourism. It is undeniable that the surrounding community also feels that tourism development produces various impacts. At the same time, social exchange theory states that two parties make exchanges based on benefits and costs, and exchange can be achieved only if both parties feel that they get more benefits from the exchange (Su et al., 2018). Thus, between the two (stakeholders and local residents) to get more benefits, involvement in the tourism development process is needed which in turn contributes to a sustainable destination (Cheng and Wu, 2015; Su and Swanson, 2017; Wilopo et al., 2020). This will certainly have an impact in terms of social and economic aspects and even the environment from the development of tourism (Yoon et al., 2001) which are felt by different groups in the local community. However, not all tourism impacts are always beneficial. There are negative effects that appear that are felt by the surrounding community.

As tourism activities progress, the impact is felt differently in various regions, where adverse activities will trigger residents to harbor hatred and have a negative attitude towards tourism (Akis et al., 1995). In principle, the impact of tourism can be positive or negative, and following three basic categories of benefits and costs, namely economic, sociocultural and environmental impacts (Brida et al., 2011). Unfortunately, the negative impact is sometimes ignored because the economic benefits provided are greater. As postulated by the Social Exchange Theory, local residents are more likely to support tourism development as long as they feel that the benefits of tourism development outweigh the associated development costs. Residents who perceive tourism development as having a positive impact on the environment tend to support the industry, while those who perceive tourism as an agent of environmental destruction tend to oppose its development (Hateftabar and Chapuis, 2020; Vargas et al., 2011; Butler, 1980). In general, various studies show that overall population support for tourism development is influenced by perceived environmental, socio-cultural, and economic benefits and costs (Lunberg, 2017; Almeida et al., 2016; Weaver and Lawton, 2013; Deery et al.,2012).

\section{METHOD}

This study empirically examines the influence of planning, the impact of tourism from the perspective of residents on tourism development. Quantitative techniques are used in this study through the distribution of online questionnaires during April 2021 to residents in the tourist area of Malang City with a sample of 200 people. The respondents of this study were local residents in the Colorful Village (Kampung Warna-Warni) and 3D Village (Kampung 3D) as a destination which choice in the strategic planning of Malang City. Therefore, the researchers used a quota sampling technique, in which each destination has a quota of 100 people. PLS-SEM was used in this study for statistical analysis and hypothesis testing. As recommended by Hair et al. (2014), PLS-SEM is a powerful statistical tool because it can be applied to all data scales, does not require many assumptions, and confirms relationships that do not yet have a strong theoretical basis. In relation to data processing, the PLS approach is used as a causal modeling approach and aims to maximize the explained variance of the dependent latent construct. In addition, PLS can also be used to develop hypotheses and predict complex situations. PLS differs from SEM in that it must meet theoretical evidence with clear parametric assumptions (Hair et al., 2014). Measurement of reliability in PLS-SEM uses Cronbach's and composite reliability with standard indicator loading of 0.70 , while validity uses average variance extracted (AVE) with an acceptable value of more than 0.50 , as recommended by Hair et al. (2014). The variables of this study were measured using a Linkert point scale of 1-5 (strongly disagree, disagree, undecided, agree, strongly agree). The indicators for each variable were obtained from various previous studies, Long-term Planning (Choi and Sirakaya, 2005), Political Participation and Local Planning Policy (Asmelash and Kumar, 2019), 
Institutional Sustainability (Cottrel and Vaske, 2006), Economic Impact (Dyer et al., 2007), Environmental Impact and Social-Cultural Impact (Almeida et al., 2016), Tourism development (Woosnam, 2010).

\section{RESULT AND ANALYSIS}

Malang City tourism development has been carried out in stages by relying on heritage tourism as a leading tourism. The tourism development program certainly needs to be supported by the local community which is the government's goal in the welfare of the community. Therefore, this study investigates the local community's perception of the tourism development launched by the government. This study has distributed questionnaires to local communities which are presented in Table 1 below regarding the demographic characteristics of the respondents.

Tabel 1. Demographic Charactersitcs of Respondent

\begin{tabular}{|c|c|c|c|}
\hline \multicolumn{2}{|c|}{ Demographic } & Frequency (n) & Persentase (\%) \\
\hline \multirow{4}{*}{ Gender } & Male & 119 & 59.5 \\
\cline { 2 - 4 } & Female & 81 & 40.5 \\
\hline \multirow{4}{*}{ Age } & $20-25$ & 34 & 17 \\
\cline { 2 - 4 } & $26-30$ & 45 & 22.5 \\
\cline { 2 - 4 } & $31-35$ & 52 & 26 \\
\cline { 2 - 4 } & $36-40$ & 55 & 27.5 \\
\cline { 2 - 4 } & $\geq 41$ & 14 & 7 \\
\hline \multirow{3}{*}{$\begin{array}{l}\text { Educa- } \\
\text { tional } \\
\text { Level }\end{array}$} & High school & 67 & 33.5 \\
\cline { 2 - 4 } & Undergraduate & 108 & 54 \\
\cline { 2 - 4 } & Master's degree & 20 & 10 \\
\cline { 2 - 4 } & Doctoral degree & 5 & 2.5 \\
\hline
\end{tabular}

The overall sample consisted of 119 men (59.5 percent) and 81 women (40.5 percent). Most respondents (27.5 percent, $\mathrm{n}=55$ ) were $36-40$ years old, 26 percent $(n=52)$ were $31-35$ years old, 22.5 percent $(n=45)$ were $26-30$ years old, 17 percent $(n=34)$ aged 20-25 years, and 7 percent $(n=14)$ aged 41 years. Meanwhile, the education level is as follows: 67 (33.5 percent) of the respondents are high school graduates, 108 (54 percent) of the respondents are undergraduate graduates, 20 (10 percent) are master's degrees, and 5 (2.5 percent) are doctoral graduates. Table 2 shows construct measurements for descriptive statistics (mean, standard deviation) and measurements proposed for the study and explains the reliability and validity assumptions using PLSSEM. Based on Hairet al. (2014) recommendations, composite reliability and Cronbach's determine reliability, so all items must be greater than 0.70 . In this study all variables have a high composite reliability value, which is more than 0.8 , among others, 0.849 (Long-Term Planning), 0.859 (Political Participation), 0.876 (Local Planning), 0.906 (Institutional Sustainability), 0.888 (Perceived Economic Impact), 0.934 (Perceived Environmental Impact), 0.926 (Perceived SociqlCulture Impact) and 0.952 (Tousim Development). Furthermore, Cronbach's for all variables has a value of more than 0.7: 0.731 (Long-Term Planning), 0.757 (Political Participation), 0.789 (Local Planning), 0.876 (Institutional Sustainability), 0.835 (Perceived Economic Impact), 0.906 (Perceived Environment Impact), 0.912 (Perceived SocialCulture Impact), 0.944 (Tourism Development). All of these values are considered acceptable and confirmed quite reliably. To ensure validity, show that a set of indicators represent the same basic construct, which can be demonstrated through its unidimensionality. The validity of the discriminant variable is proven by calculating the extraction average value (AVE) and the value obtained between variables. That is, the AVE value for all variables is greater than 0.5 , indicating that the variables of convergent validity are sufficient (Hair, 2019). Furthermore, each variable is measured and has a value of more than 0.5: for example 0.653 (Long-Term Planning), 0.670 (Political Participation), 0.701 (Local

Table 2. Reliability and Validity Construct

\begin{tabular}{|c|c|c|c|c|c|c|}
\hline Variables & Item & Mean & $\begin{array}{l}\text { Standard } \\
\text { Deviation }\end{array}$ & $\begin{array}{l}\text { Cron- } \\
\text { bach's } \\
\beta\end{array}$ & $\begin{array}{l}\text { Composite } \\
\text { Reliability }\end{array}$ & $\begin{array}{l}\text { Average Vari- } \\
\text { ance Extracted } \\
\text { (AVE) }\end{array}$ \\
\hline \multirow{3}{*}{$\begin{array}{l}\text { Long-Term } \\
\text { Planning }\end{array}$} & LTP1 & 4.364 & 0.900 & & & \\
\hline & LTP2 & 4.013 & 0.780 & & & \\
\hline & LTP3 & 3.876 & 0.620 & & & \\
\hline & & & & 0.731 & 0.849 & 0.653 \\
\hline \multirow{4}{*}{$\begin{array}{c}\text { Political } \\
\text { Participation }\end{array}$} & POP1 & 3.964 & 0.617 & & & \\
\hline & POP2 & 4.227 & 0.852 & & & \\
\hline & POP3 & 3.951 & 0.707 & & & \\
\hline & & & & $\mathbf{0 . 7 5 7}$ & 0.859 & 0.670 \\
\hline \multirow{4}{*}{$\begin{array}{l}\text { Local } \\
\text { Planning } \\
\text { Policy }\end{array}$} & LPP1 & 3.978 & 0.643 & & & \\
\hline & LPP2 & 4.204 & 0.824 & & & \\
\hline & LPP3 & 4.004 & 0.670 & & & \\
\hline & & & & $\begin{array}{l}0.789 \\
\end{array}$ & 0.876 & 0.701 \\
\hline \multirow{7}{*}{$\begin{array}{l}\text { Institutional } \\
\text { Sustainability }\end{array}$} & IS1 & 4.147 & 0.859 & & & \\
\hline & IS2 & 4.142 & 0.759 & & & \\
\hline & IS3 & 3.938 & 0.752 & & & \\
\hline & IS4 & 4.271 & 0.860 & & & \\
\hline & IS5 & 4.249 & 0.843 & & & \\
\hline & IS6 & 4.311 & 0.854 & & & \\
\hline & & & & 0.876 & 0.906 & 0.618 \\
\hline \multirow{5}{*}{$\begin{array}{l}\text { Perceived } \\
\text { Economic } \\
\text { Impact }\end{array}$} & Eco_I1 & 4.027 & 0.742 & & & \\
\hline & Eco_I2 & 3.973 & 0.666 & & & \\
\hline & Eco_I3 & 4.231 & 0.848 & & & \\
\hline & Eco_I4 & 4.013 & 0.696 & & & \\
\hline & & & & $\mathbf{0 . 8 3 5}$ & 0.888 & 0.665 \\
\hline \multirow{4}{*}{$\begin{array}{c}\text { Perceived } \\
\text { Environment } \\
\text { Impact }\end{array}$} & Env_I1 & 3.956 & 0.804 & & & \\
\hline & Env_I2 & 3.982 & 0.800 & & & \\
\hline & Env_I3 & 4.004 & 0.892 & & & \\
\hline & Env_I4 & 3.969 & 0.866 & & & \\
\hline & & & & 0.906 & 0.934 & 0.780 \\
\hline \multirow{11}{*}{$\begin{array}{l}\text { Perceived } \\
\text { Social- } \\
\text { Culture } \\
\text { Impact }\end{array}$} & SC1 & 4.191 & 0.945 & & & \\
\hline & $\mathrm{SC} 2$ & 4.204 & 0.824 & & & \\
\hline & SC3 & 3.924 & 0.723 & & & \\
\hline & SC4 & 3.969 & 0.599 & & & \\
\hline & SC5 & 4.382 & 0.763 & & & \\
\hline & SC6 & 4.120 & 0.765 & & & \\
\hline & SC7 & 4.111 & 0.694 & & & \\
\hline & SC8 & 4.329 & 0.899 & & & \\
\hline & SC9 & 4.147 & 0.712 & & & \\
\hline & SC10 & 4.347 & 0.907 & & & \\
\hline & & & & 0.912 & 0.926 & 0.558 \\
\hline \multirow{10}{*}{$\begin{array}{c}\text { Tourism } \\
\text { Development }\end{array}$} & TD1 & 4.156 & 0.888 & & & \\
\hline & TD2 & 4.204 & 0.891 & & & \\
\hline & TD3 & 3.858 & 0.710 & & & \\
\hline & TD4 & 3.867 & 0.680 & & & \\
\hline & TD5 & 4.076 & 0.928 & & & \\
\hline & TD6 & 3.889 & 0.767 & & & \\
\hline & TD7 & 4.089 & 0.890 & & & \\
\hline & TD8 & 3.973 & 0.827 & & & \\
\hline & TD9 & 3.911 & 0.755 & & & \\
\hline & & & & 0.944 & 0.952 & 0.688 \\
\hline
\end{tabular}


Planning), 0.618 (Institutional Sustainability), 0.665 (Perceived Economic Impact), 0.780 (Perceived Environment Impact), 0.558 (Perceived Social-Culture Impact), 0.688 (Tourism Development). That AVE is a measure of communality for each latent variable (Hair et al., 2014) and shows adequate results because all variants show a value each exhibit above 0.50 . Thus, the measurement of the construct of this research is indicated to be strong.

This study has nine relevant hypotheses tested using a statistical approach with PLS-SEM. It determines model-fit and path coefficients as quantities used in determining the overall relationship effect in the model. Regarding the sequential partial model was determined to run statistical analysis. Thus, the first hypothesis, the effect of long term planning is tested with institutional sustainability which shows a positive and significant effect (LTP $=0.170$, p-value $<0.05$ ) and therefore H1 is accepted. The second hypothesis, Political Participation in institutional sustainability was tested and the results showed that it was not significant $(\mathrm{POP}=0.046, \mathrm{p}$-value $>0.05)$ to conclude that it was rejected for $\mathrm{H} 2$. While the third hypothesis gives the results of the relationship between long term planning and institutional sustainability and shows a positive and significant effect ( $\mathrm{LPP}=0.650$, p-value $<0.05$ ), so $\mathrm{H} 3$ can be accepted. In addition, the fourth hypothesis shows that institutional sustainability on the perceived economic impact has a significant effect (IS $=0.776$, p-value $>0.05$ ), so $\mathrm{H} 4$ is accepted. The fifth hypothesis shows that the relationship between institutional sustainability and perceived environmental impact has a negative and significant effect (iS=-0.111, p-value <0.05), so $\mathrm{H} 5$ is rejected. While the results of testing the relationship between institutional sustainability and perceived socio-culture showed a positive and significant effect (IS = 0.761, p-value <0.05), then $\mathrm{H} 6$ was accepted. Table 3 also presents the mediating role of destination image from program content, quality of facilities, convenience, quality of information, and staff on revisit intentions, the implications of which will also be discussed. The seventh hypothesis, namely the effect of perceived economic impact, was tested with tourism development which showed a positive but not significant effect (Eco_I $=0.011$, p-value $<0.05$ ) and therefore H7 was rejected. Then, the eighth hypothesis, namely testing the effect of perceived environmental impact on tourism development, was tested and showed significant and positive results (Env_I $=0.366$, p-value> 0.05 ) so that $\mathrm{H} 8$ was accepted. While the ninth hypothesis gives an insignificant relationship between socio-culture and tourism development ( $\mathrm{SC}=0.033$, $\mathrm{p}$-value $<0.05$ ), so $\mathrm{H} 9$ can be rejected. Table 3 also presents the mediating role of destination image from program content, quality of facilities, convenience, quality of information, and staff on revisit intentions, the implications of which will also be discussed.

Table 3. Hypothesis Testing

\begin{tabular}{|c|c|c|c|c|c|}
\hline Reliationships & Direct Effect ( $\beta$ ) & Indirect Effect $(\beta)$ & T-Score & Probability & \begin{tabular}{|l|} 
Conclusion \\
\end{tabular} \\
\hline$\overline{\text { LTP }} \square$ IS & 0.170 & & 2.957 & 0.003 & Accepted \\
\hline POP $\square$ IS & 0.046 & & 0.604 & 0.546 & Rejected \\
\hline LPP $\square$ IS & 0.650 & & 8.558 & 0.000 & Accepted \\
\hline IS $\square$ Eco_I & 0.776 & & 23.566 & 0.000 & Accepted \\
\hline IS $\square$ Env_I & -0.112 & & 2.856 & 0.004 & Accepted \\
\hline IS $\square$ SC & 0.761 & & 18.723 & 0.000 & Accepted \\
\hline Eco_I $\square$ TD & 0.011 & & 0.076 & 0.940 & Rejected \\
\hline Env_I $\square$ TD & 0.366 & & 3.659 & 0.000 & Accepted \\
\hline $\mathrm{SC} \square \mathrm{TD}$ & 0.033 & & 0.228 & 0.820 & Rejected \\
\hline$\overline{\text { LTP }} \square$ IS $\square$ Eco_I & 0.132 & 2.898 & & 0.004 & Accepted \\
\hline POP $\square$ IS $\square$ Eco_I & 0.036 & 0.599 & & 0.549 & Rejected \\
\hline LPP $\square$ IS $\square$ Eco_I & 0.505 & 7.522 & & 0.000 & Accepted \\
\hline LTP $\square$ IS $\square$ Env_I & -0.019 & 2.070 & & 0.039 & Accepted \\
\hline POP $\square$ IS $\square$ Env_I & -0.005 & 0.557 & & 0.578 & Rejected \\
\hline LPP $\square$ IS $\square$ Env_I & -0.073 & 2.614 & & 0.009 & Accepted \\
\hline LTP $\square$ IS $\square$ SC & 0.130 & 2.786 & & 0.006 & Accepted \\
\hline POP $\square$ IS $\square$ SC & 0.035 & 0.594 & & 0.553 & Rejected \\
\hline LPP $\square$ IS $\square$ SC & 0.495 & 7.878 & & 0.000 & Accepted \\
\hline
\end{tabular}

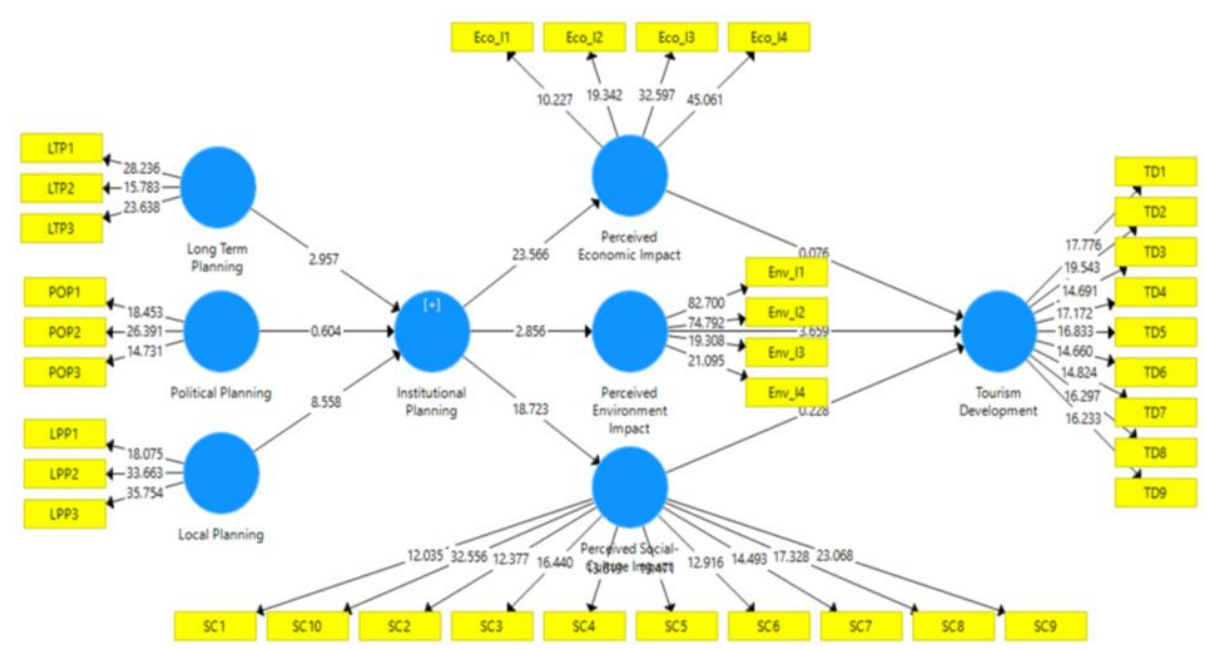

Figure 2. Structural Model Output

\section{DISCUSSION}

The findings in this study revolve around three main areas to give particular attention to tourism development in the context of local people's perceptions. First, tourism planning as defined earlier. Second, institutional stability was found to influence the success and subjective perception of tourism planning in tourist destinations in Malang City. Third, the results regarding the impacts of tourism that are felt by the community regarding tourism that have an impact on the main impetus for tourism development are summarized. Finally, a collaborative tourism planning process to improve subjective well-being at the local level (Hemmonsbey and Tichaawa, 2019). Optimal tourism planning is a must to achieve sustainability which is one of the most significant influences on how tourism develops which are closely interrelated in the context of tourism governance (Dredge and Jenkins, 2007). In this study, attention is directed to the point of view of tourism planning which has not been widely discussed. The results of this study are in line with previous research which reflects that good long-term tourism planning can promote good governance (Ampong, 2018; Gibson, 2009). Furthermore, effective tourism planning can help in dealing 
with the negative consequences of this sector, especially environmental and community impacts so that governance tends to be more stable (Almeida et al., 2017). Apart from that, as a framework for decision making, long-term planning is also a guide for all future development activities. With clear long-term planning, the government and local communities can identify the strengths and weaknesses of a tourism product, define a set of goals and objectives. An area that has the right long-term planning allows it to maximize all its potential so that it does not only focus on instantaneous profits. The longterm planning carried out by the City of Malang related to tourism has been contained in the Regional Tourism Development Master Plan (RIPPD) which was formulated to realize the leading tourism of Malang City.

Political participation is one of the recommended topics in tourism development. With the participation of the community in planning, it will bring up a shared view of tourism development (Ramukumba, 2019). This type of tourism planning process allows many tourism actors to consider tourism development and how their well-being will be affected by tourism growth (Jamal and Getz, 1995). An example of participation in planning is a public meeting with the actors involved with the opportunity to respond to a planning proposal (Buanes et al., 2005). In addition, recent research on planning models has shown that community-involved tourism plans are more successfully implemented and maintained than other types of tourism planning (Plummer et al., 2006). The tourism planning developed in Malang City has not involved the community much in its preparation. Meanwhile, the problem that may be faced by the government according to Forester (1982) is that when producing an effective plan, a public planner will experience confusion in his alignment with a decision. People's input comes from the point of view of ordinary people and may lack the technical background and knowledge needed later in decision making so they are not too much involved in planning. In addition to the aspect of involvement in planning, the focus of the policy planning taken also needs to be adjusted to certain regions. Therefore, regional policy planning is formed so that tourism development can optimize every advantage that exists in the region. This shows that the tourism sector certainly requires a tourism development plan that is specifically structured according to the potential of an area. Malang City itself has issued several regional regulations that regulate the tourism process so that Malang City's local policy is considered adequate. The results of this study support the opinion of several previous studies which state that tourism development can be influenced by local environmental, social and economic contexts which may require more attention to certain aspects than others (Lawton and Weaver, 2015; Harrill and Potts, 2003). In the tourism process, policy can be used to regulate stakeholders and as a tool to prevent potential conflicts (Beritelli and Laesser, 2011). With a strong link between local policies for development prevents inappropriate implementation at a local scale and helps find solutions that are shared by local communities and targeted at specific priorities.

Governments change over time as they adapt to evolving social circumstances, such as "shifts in the influence of influential actors or hegemonic values" (Dredge and Jenkins, 2007). Changes in extreme conditions such as environmental, economic and social conditions as well as inappropriate government activities can be factors that undermine institutional stability. Meanwhile, to support tourism development optimally, institutional stability is needed because it affects various aspects of tourism. The positive and significant influence is shown by the results of the study in Table 3 for institutional stability on the perceived economic impact of the local community. Stability in government is a political construction affecting the economy that involves the process of mobilizing and coordinating social action so that it affects economic conditions (Beaumont and Dredge, 2010). The economic impact of institutional stability has been widely applied in the social sciences, but rarely in tourism (Bramwell, 2010). A positive relationship shows that the government is considered to help regulate the community to reduce various economic crises with its stability in tourism development. Political legitimacy in the context of unstable social relations leads to the failure of the necessary authorities to regulate the economy. Then, this study also examines the indirect effect of long term planning, political participation and local planning policy through institutional sustainability. However, only long term planning and local planning policies were accepted, while political planning had no significant effect.

The current stability of the Malang City government which is considered not to have a positive environmental impact. The lack of environmental care activities with the existence of tourism carried out by the City of Malang is one of the causes. The difficulties experienced are expressed by Hall (2003) where ecotourism policies are more complicated because economic impacts tend to be prioritized. A very constructive role cannot be ignored in the process of economic growth and development, but at the same time the environmental aspect cannot be ruled out because it also affects social welfare (Rogerson and Rogerson, 2019). The results of the research by Xuchao et al. (2010) stated that energy consumption and $\mathrm{CO}_{2}$ emissions are mainly caused by the hotel and tourism industry. Negative environmental impacts can certainly be minimized by making appropriate policies that require government stability as the executor. Institutional stability is seen as capable of providing tourism development that is compatible with the maintenance of vital ecological processes, diversity and biological resources (Katerina and Gabriela, 2012).

Furthermore, to examine the indirect effect, this study also measures the mediating role of institutional sustainability from long term planning, political participation and local planning policy through institutional sustainability. However, only long-term planning and local planning policies were accepted, while political planning had no significant effect. Perceptions related to the social impact of tourism in this study are related to positive or negative changes in social and cultural conditions (Park, 2007). Tourism itself is a social phenomenon that also plays a role in producing places and preserving culture and the development of social activities. Good institutional stability guarantees social welfare and the protection of local culture. It is very important for the government to understand how people perceive the benefits and disadvantages of tourism. Several studies state that institutional stability makes it easier for people to obtain better social welfare because it reflects better tourism planning and development (Deery et al., 2010). This welfare can be in the form of encouraging cultural activities, improving infrastructure and increasing security and living standards of local 
communities. Indirect influence is also measured which shows the results that long-term planning and local planning policies are accepted, while political planning does not have a significant influence. Community support related to tourism development is generally divided into two categories, namely economic and non-economic rationality.

The first category emphasizes residents' perceptions of the economic impact of tourism development and relies on calculating material benefits to explain supportive attitudes and behaviors (Nunkoo and Gursoy, 2012; Nunkoo and Ramkissoon, 2011). The results of this study are certainly contrary to the principle of the direction of tourism development in Malang City which focuses on increasing employment opportunities so that it can accelerate economic growth and alleviate poverty. According to social exchange theory, residents' perceptions of the benefits and costs incurred can determine support for tourism (McGehee and Anderek, 2004).

Low or even negative economic impact is a trigger for rejection of tourism development (Nunkoo and Gursoy, 2012). Then, when this research was conducted, the condition of tourism in Malang City experienced a drastic decline which also affected the local community's economy. In addition, the situation where the economic impact felt by tourism and institutional stability may be uneven and only focuses on a few major tourist destinations is also the cause. The most influential important factor in explaining tourism support is the personal economic benefits derived from tourism (Dyer et al., 2007; Gursoy et al., 2010), especially in areas where tourism is expected to alleviate poverty or become a pillar industry (Gursoy and Rutherford, 2004). So by ensuring a balanced exchange between the benefits expected by the whole society received from tourism it becomes a tool for driving tourism development.

There is no doubt that people's views on environmental impacts have changed over time. Every development activity leads to environmental change, tourism is one of them (Lee et al., 2013). Tourism often has the potential to contribute positively to local development but at the same time, its rapid and sometimes uncontrolled growth can be a major cause of environmental degradation and loss of local identity and traditional culture (Zhang and Gao, 2016). Errors in planning tourism activities due to government instability can intensify natural degradation and environmental damage. Various studies reveal negative environmental impacts of tourism (eg, Barros et al, 2013; Rashid and Romshoo, 2012). Malang city itself has great natural tourism potential. Nature-based tourism itself has long been recognized as an agent of ecological change in natural systems (Monz et al., 2010). However, the results of research showing a positive influence indicate that the development of natural environmental conditions due to tourism has a positive impact. One of the phenomena that occurs is the emergence of various new tourist attractions based on local wisdom which used to be slum housing. The tourist destinations here have the effect of increasing the environmental index significantly higher than the surrounding non-tourism areas. With this positive perception, it will increase local community support regarding tourism development (Ramukumba, 2019). The next focus is the social and cultural perceptions felt by the local community as a result of tourism activities on tourism development. Some researchers have argued that people's support for tourism is likely to depend on the emotions, affections, and beliefs that shape behavior (Lee et al., 2012; Boley et al., 2017). Similar to economic perceptions, tourism development support is also measured based on the perceived social impact (Adinolfi, 2019). The results of this study indicate that social and cultural perceptions are not the main predictors of tourism development. This is explained by Deery et al (2012) who state that the social impact of tourism cannot be overestimated. The perception of the social and cultural impact felt by the community from tourism is not too large due to a decline in tourism activity during Covid-19. The interactions that exist automatically also decrease so that the socio-cultural impact is not significant.

\section{Implications, limitations, and future research}

Local community planning and support is very important in tourism development. Experts have identified suitable planning models in tourism development, but few have taken into account the stability of the institution and the perceived impact on the community. Stakeholder theory is used to examine the most ideal tourism planning. Meanwhile, Social Exchange Theory is used to see the perception of the local community in supporting tourism development. The findings of this study can broaden the theoretical perspective regarding the complexity of planning and community support for tourism. Furthermore, this research provides important insights to the city government regarding tourism development planning. Based on this research, institutional stability is a key factor influencing people's perceptions of tourism development. Tourism planners should also emphasize citizen participation and pay attention to profit sharing in supporting the economic and social impacts of tourism development. Although tourism brings tremendous benefits, the positive impacts are not being felt evenly and the Covid-19 pandemic is making things worse. The government needs to pay attention to the comparison of benefits can create a sense of injustice, which can greatly weaken local community support for tourism. Tourism planners should also seek to identify the negative impacts of tourism activities. Planners should consider that the community is not a tourist attraction that is intended only to meet the needs of tourists. More attention needs to be paid to the daily comfort of residents and the safety of residents when planning tourism projects. Although this study made some important contributions, some limitations need to be considered to support future research. First, this study only measures tourism planning that focuses on the region and does not discuss it at a higher level. Future research can evaluate higher-level policies and their alignment with existing local policies. Furthermore, this study only examines the perception of the impact of tourism from local communities in tourist destinations; in fact, the impact of tourism development on other stakeholders such as restaurants, transportation bureaus and shopping centers is also felt. Future research should evaluate the perceptions of other tourism stakeholders in more detail.

\section{REFFERENCES}

Adinolfi, M.C. (2019). Social Capital and The Making of Diaspora: Evidence from The Portuguese Community of Johannesburg, South Africa. GeoJournal of Tourism and Geosites, 25 (2), 555-568. https://doi.org/10.30892/gtg.25222-380 
Adongo, R., Kim, S.S., \& Elliot, S. (2019). "Give and take": A social exchange perspective on festival stakeholder relations. Annals of Tourism Research, 75, 42-57. https://doi.org/10.1016/j.annals.2018.12.005

Akis, S., Peristianis, N., \& Warner, J. (1996). Residents' attitude to tourism development: The case of Cyprus. Tour. Manag., 17, 481494. https://doi.org/10.1016/S0261-5177(96)00066-0

Almeida, J., Costa, C., \& da Silva, F.N. (2017). A framework for conflict analysis in spatial planning for tourism. Tourism Management Perspectives, 24, 94-106. https://doi.org/10.1016/j.tmp.2017.07.021

Almeida-García, F., Peláez-Fernández, M.Á., Balbuena-Vázquez, A., \& Cortés-Macias, R. (2016). Residents' perceptions of tourism development in Benalmádena (Spain). Tourism Management, 54, 259-274. https://doi.org/10.1016/j.tourman.2015.11.007

Ampong, Emmanuel (2018). Tourism and national economic development planning in Ghana, 1964-2014. International Development Planning Review, 40 (1), 75-95. https://doi.org/10.3828/idpr.2018.2

Andereck, K.L., \& Nyaupane, G.P. (2010). Exploring the Nature of Tourism and Quality of Life Perceptions among Residents. Journal of Travel Research, 50(3), 248-260. https://doi.org/10.1177/0047287510362918

Andereck, K.L., Valentine, K.M., Knopf, R.C., \& Vogt, C.A. (2005). Residents' perceptions of community tourism impacts. Annals of Tourism Research, 32(4), 1056-1076. https://doi.org/10.1016/j.annals.2005.03.001

Andereck, K.L., \& Vogt, C.A. (2000). The relationship between citizens' attitudes towards tourism and tourism development choices. Journal of Travel Research 39(1), 27-36. https://doi.org/10.1177/004728750003900104

Angelevska-Najdeska, K., \& Rakicevik, G. (2012). Planning of Sustainable Tourism Development. Procedia - Social and Behavioral Sciences, 44, 210-220. https://doi.org/10.1016/j.sbspro.2012.05.022

Asmelash, A.G., \& Kumar, S. (2019). Corrigendum to "Assessing progress of tourism sustainability: Developing and validating sustainability indicators". Tourism Management, 71, 67-83. https://doi.org/10.1016/j.tourman.2019.02.007

Barros, A., Gonnet, J., \& Pickering, C. (2013). Impacts of informal trails on vegetation and soils in the highest protected area in the Southern Hemisphere. Journal of Environmental Management, 127, 50-60. https://doi.org/10.1016/j.jenvman.2013.04.030

Beaumont, N., \& Dredge, D. (2010). Local tourism governance: a comparison of three network approaches. Journal of Sustainable Tourism, 18(1), 7-28. https://doi.org/10.1080/09669580903215139

Beritelli, P., \& Laesser, C. (2011). Power dimensions and influence reputation in tourist destinations: Empirical evidence from a network of actors and stakeholders. Tourism Management, 32(6), 1299-1309. https://doi.org/10.1016/j.tourman.2010.12.010

Bianchi, R. (2018). The political economy of tourism development: A critical review. Annals of Tourism Research, 70, 88102. https://doi.org/10.1016/j.annals.2017.08.005

Bichler, B.F., \& Lösch, M. (2019). Collaborative Governance in Tourism: Empirical Insights into a Community-Oriented Destination. Sustainability, 11(23), 6673. https://doi.org/10.3390/su11236673

Boley, B.B., \& Strzelecka, M., \& Woosnam, K.M. (2018). Resident perceptions of the economic benefits of tourism: Toward a common measure. Journal of Hospitality \& Tourism Research, 42(8), 1295-1314. https://doi.org/10.1177/1096348018759056

Bramwell, B. (2010). Participative Planning and Governance for Sustainable Tourism. Tourism Recreation Research, 35(3), $239-249$. https://doi.org/10.1080/02508281.2010.11081640

Bregoli, I. (2012). Effects of DMO Coordination on Destination Brand Identity. Journal of Travel Research, 52(2), 212-224. https://doi.org/10.1177/0047287512461566

Brida, J.G., Osti, L., \& Faccioli, M. (1996). Residents' perception and attitudes towards tourism impacts: A case study of the small rural community of Folgaria (Trentino-Italy). Benchmarking Int. J., 18, 359-385. https://doi.org/10.1108/14635771111137769

Buanes, A., Jentoft, S., Maurstad, A., Sreng, S., \& Karlsen, G. (2005). Stakeholder participation in Norwegian coastal zone planning. Ocean and Coastal Management 48 (9-10), 658- 669. https://doi.org/10.1016/j.ocecoaman.2005.05.005

Buhalis, D. \& Amaranggana, A. (2104). Information and Communication Technologies in Tourism 2014. Proceedings of the International Conference in Dublin, Ireland, 553-564.

Butler, R.W. (1980). The concept of a tourist area cycle of evolution: Implications for management of resources. The Canadian Geographer/Le Géographe Canadien, 24(1), 5-12. https://doi.org/10.21832/9781845410278-007

Byrd, E.T. (2007). Stakeholders in sustainable tourism development and their roles: applying stakeholder theory to sustainable touris $\mathrm{m}$ development. Tourism Review, 62(2), 6-13. https://doi.org/10.1108/16605370780000309

Byrd, E.T., Bosley, H.E., \& Dronberger, M.G. (2009). Comparisons of stakeholder perceptions of tourism impacts in rural eastern North Carolina. Tourism Management, 30(5), 693-703. https://doi.org/10.1016/j.tourman.2008.10.021

Cheng, T.M., \& Wu, H.C. (2015). How do environmental knowledge, environmental sensitivity, and place attachment affect environmentally responsible behavior? An integrated approach for sustainable island tourism. Journal of Sustainable Tourism, 23(4), 557-576. https://doi.org/10.1080/09669582.2014.965177

Choi, H.S.C., \& Sirakaya, E. (2005). Measuring residents' attitude towards sustainable tourism: development of sustainable tourism attitude scale. Journal of Travel Research, 43(4), 380-394. https://doi.org/10.1177/0047287505274651

Cottrel, S.P., \& Vaske, J.J. (2006). A framework for monitoring and modeling sustainable tourism. E-review of Tourism Research, 4 (4), 74-84. http://agrilife.org/ertr/files/2012/09/201_a-4-4-1.pdf.

d' Angella, F., \& Go, F.M. (2009). Tale of two cities' collaborative tourism marketing: Towards a theory of destination stakeholder assessment. Tourism Management, 30(3), 429-440. https://doi.org/10.1016/j.tourman.2008.07.012

Dabphet, S., Scott, N., \& Ruhanen, L. (2012). Applying diffusion theory to destination stakeholder understanding of sustainable tourism development: A case from Thailand. Journal of Sustainable Tourism, 20(8), 110-1124. https://doi.org/10.1080/09669582.2012.673618

Deery, M., Jago, L., \& Fredline, L. (2012). Rethinking social impacts of tourism research: A new research agenda. Tourism Management, 33(1), 64-73. https://doi.org/10.1016/j.tourman.2011.01.026

Diedrich, A., \& García-Buades, E. (2009). Local perceptions of tourism as indicators of destination decline. Tourism Management, 30(4), 512-521. https://doi.org/10.1016/j.tourman.2008.10.009

Dodds, R. (2007). Sustainable tourism and policy implementation: Lessons from the case of Calvia, Spain. Current Issues in Tourism, 10 (4), 296-322. https://doi.org/10.2167/cit278.0

Dredge, D., \& Jenkins, J. (2007). Tourism planning and policy. John Wiley.

Dyer, P., Gursoy, D., Sharma, B., \& Carter, J. (2007). Structural modeling of resident perceptions of tourism and associated development on the Sunshine Coast, Australia. Tourism management, 28(2), 409-422. https://doi.org/10.1016/j.tourman.2006.04.002

Forester, J. (1982). Planning in the Face of Power. Journal of the American Planning Association, 48(1), 67-80. https://doi.org/10.1080/01944368208976167

Forester, J. (2000). The deliberative planning Process: Encouraging participatory planning processes. Cambridge and London: MIT Press.

Fredline, E., \& Faulkner, B. (2000). Host community reactions: A cluster analysis. Annals of Tourism Research,27(3), 763-784. https://doi.org/10.1016/S0160-7383(99)00103-6

Gibson, C. (2009). Geographies of tourism: Critical research on capitalism and local livelihoods. Progress in Human Geography, 33(4), 527-534. https://doi.org/10.1177/0309132508099797 
Goeldner, C.R., \& Ritchie, J.R.B. (2009). Tourism: Principles, Practices, Philosophies. Wiley.

Gursoy, D., \& Rutherford, D.G. (2004). Host attitudes toward tourism. Annals of Tourism Research, 31(3), 495-516. https://doi.org/10.1016/j.annals.2003.08.008

Gursoy, D., Chi, C.G., \& Dyer, P. (2010). Locals' attitudes toward mass and alternative tourism: The case of Sunshine Coast, Australia. Journal of travel research, 49(3), 381-394. https://doi.org/10.1177/0047287509346853

Hair Jr, J.F., Sarstedt, M., Hopkins, L., \& Kuppelwieser, V.G. (2014). Partial least squares structural equation modeling (PLS-SEM): An emerging tool in business research. European Business Review, 26(2), 106-121. https://doi.org/10.1108/EBR-10-2013-0128

Hall, C. (2003). Politics and place: An analysis of power in tourism communities (pp. 99e113). Wallingford, UK: CABI.

Hall, C. (2008). Tourism planning: Policies, processes and relationships. Pearson Education.

Hallak, R., Assaker, G., \& Lee, C. (2012). Tourism Entrepreneurship Performance. Journal of Travel Research, 54(1), 36-51. https://doi.org/10.1177/0047287513513170

Harrill, R., \& Potts, T.D. (2003). Tourism planning in historic districts: Attitudes toward tourism development in Charleston. Journal of American Planning Association, 69(3), 233-244. https://doi.org/10.1080/01944360308978017

Harrill, R. (2004). Residents' attitudes toward tourism development: A literature review with implications for tourism planning. Journal of Planning Literature, 18(3), 251-266. https://doi.org/10.1177/0885412203260306

Hateftabar, F., \& Chapuis, J.M. (2020). How resident perception of economic crisis influences their perception of tourism. Journal of Hospitality and Tourism Management, 43, 157-168. https://doi.org/10.1016/j.jhtm.2020.02.009

Hayati, Y., Adrianto, L., Krisanti, M., Pranowo, W.S., \& Kurniawan, F. (2020). Magnitudes and tourist perception of marine debris on small tourism island: Assessment of Tidung Island, Jakarta, Indonesia. Marine Pollution Bulletin, 158, 111393. https://doi.org/10.1016/j.marpolbul.2020.111393

Hemmonsbey, J.D., \& Tichaawa, T.M. (2019). Strategic planning of sport tourism events on destination brands: Examining the role of home-grown sport. Geojournal of Tourism and Geosites, 26(3), 794-807. https://doi.org/10.30892/gtg.26310-398

Jamal, T., \& Camargo, B.A. (2018). Tourism governance and policy: Whither justice?. Tourism management perspectives, $25,205-208$. https://doi.org/10.1016/j.tmp.2017.11.009

Jamal, T.B., \& Getz, D. (1995). Collaboration theory and community tourism planning. Annals of Tourism Research, 22(1), 186-204. https://doi.org/10.1016/0160-7383(94)00067-3

Jamal, T., \& Stronza, A. (2009). Collaboration theory and tourism practice in protected areas: stakeholders, structuring and sustainability. Journal of Sustainable Tourism, 17(2), 169-189. https://doi.org/10.1080/09669580802495741

Kaiser, C., \& Helber, L. (1978). Tourism planning and development. CBI, Boston

Kang, S.K., \& Lee, J. (2018). Support of marijuana tourism in Colorado: A residents' perspective using social exchange theory. Journal of Destination Marketing \& Management, 9, 310-319. https://doi.org/10.1016/j.jdmm.2018.03.003

Katerina, A. N., \& Gabriela, R. (2012). Planning of sustainable tourism development. Procedia - Social and Behavioral, Sciences 44(2012), 210 220. https://doi:10.1016/j.sbspro.2012.05.022

Ko, T.G. (2001). Assessing progress toward sustainable tourism development. Unpublished Thesis, Sydney, Australia: University of Technology.

Lange, P., Driessen, P.P., Sauer, A., Bornemann, B., \& Burger, P. (2013). Governing towards sustainability—conceptualizing modes of governance. Journal of environmental policy \& planning, 15(3), 403-425. https://doi.org/10.1080/1523908X.2013.769414

Lawton, L., \& Weaver, D.W. (2015). Using residents' perceptions research to inform planning and management for sustainable tourism: A study of Gold Coast Schoolies Week, a contentious tourism event. Journal of Sustainable Tourism, 23 (5), 660-682. https://doi.org/10.1080/09669582.2014.991398

Lee, L.F., \& Hsieh, C.S. (2015). A Social Interactions Model with Endogenous Friendship Formation and Selectivity. Journal of Applied Econometrics, 31(2), 301-319. https://doi.org/10.1002/jae.2426

Lee, J., Kyle, G., \& Scott, D. (2012). The Mediating Effect of Place Attachment on the Relationship between Festival Satisfaction and Loyalty to the Festival Hosting Destination. Journal of Travel Research, 51(6), 754-767. https://doi.org/10.1177/0047287512437859

Lee, Y.S., Lawton, L.J., \& Weaver, D.B. (2013). Evidence for a South Korean model of ecotourism. Journal of Travel Research, 52(4), 520-533. https://doi.org/10.1177/0047287512467703

Lemy, D., Goh, E., \& Ferry, J. (2019). Moving out of the silo: How service quality innovations can develop customer loyalty in Indonesia's hotels. Journal of Vacation Marketing, 25(4), 462-479. https://doi.org/10.1177/1356766718819658

Lohman, G., \& Netto, P.A. (2016). Tourism Theory: Concepts, Models and Systems. CABI 745 Atlantic Avenue. Brazil.

Lunberg, E. (2017). The importance of tourism impacts for different local resident groups: A case study of a Swedish seaside destination. Journal of Destination Marketing \& Management, 6 (1), 46-55. https://doi.org/10.1016/j.jdmm.2016.02.002

Lynch, P., Molz, G., J., McIntosh, J., A., and Lugosi, P. (2011). Theorizing hospitality. Hospitality \& Society 1(1):3-24. https://doi.org/10.1386/hosp.1.1.3_2

Mathieson, A., \& Wall, G. (1982). Tourism: Economic, physical, and social impacts. London, New York: Longman.

McGehee, N.G., \& Andereck, K.L. (2004). Factors Predicting Rural Residents' Support of Tourism. Journal of Travel Research, 43(2), 131-140. https://doi.org/10.1177/0047287504268234

Minnaert, L. (2020). Stakeholder stories: Exploring social tourism networks. Annals of Tourism Research, 83, 102979. https://doi.org/10. 1016/j.annals.2020.102979

Monz, C.A., Marion, J.L., Goonan, K.A., Manning, R.E., Wimpey, J., \& Carr, C. (2010). Assessment and Monitoring of Recreation Impacts and Resource Conditions on Mountain Summits: Examples From the Northern Forest, USA. Mountain Research and Development, 30(4), 332-343. https://doi.org/10.1659/MRD-JOURNAL-D-09-00078.1

Moscardo, G. (2011). Exploring social representations of tourism planning: issues for governance. Journal of Sustainable Tourism, 19(45), 423-436. https://doi.org/10.1080/09669582.2011.558625

Neuts, B., \& Nijkamp, P. (2012). Tourist crowding perception and acceptability in cities. Annals of Tourism Research, 39(4), $2133-2153$. https://doi.org/10.1016/j.annals.2012.07.016

Nunkoo, R., \& Ramkissoon, H. (2011). Developing a community support model for tourism. Annals of Tourism Research, 38(3), 964988. https://doi.org/10.1016/j.annals.2011.01.017

Nunkoo, R., \& Gursoy, D. (2012). Residents' support for tourism. Annals of Tourism Research, 39(1), 243-268. https://doi.org/10. 1016/j.annals.2011.05.006

Nunkoo, R. (2016). Toward a More Comprehensive Use of Social Exchange Theory to Study Residents' Attitudes to Tourism. Procedia Economics and Finance, 39, 588-596. https://doi.org/10.1016/S2212-5671(16)30303-3

Oviedo-Garcia, M.A., Castellanos-Verdugo, M., \& Martin-Ruiz, D. (2008). Gaining residents' support for tourism and planning. International Journal of Tourism Research, 10(2), 95-109. https://doi.org/10.1002/jtr.644

Park, C. (2007). A dictionary of environment and conservation. Oxford University Press. Oxford Reference Online. Goteborg University Library (Accessed 5 March 2016). 
Perkins, R., Khoo-Lattimore, C., \& Arcodia, C. (2020). Understanding the contribution of stakeholder collaboration towards regional destination branding: A systematic narrative literature review. Journal of Hospitality and Tourism Management, 43, $250-258$. https://doi.org/10.1016/j.jhtm.2020.04.008

Petrosillo, I., Zurlini, G., Grato, E., \& Zaccarelli, N. (2006). Indicating fragility of socio-ecological tourism-based systems. Ecological Indicators, 6(1), 104-113. https://doi.org/10.1016/j.ecolind.2005.08.008

Pforr, C. (2006). Tourism Policy in the Making. Annals of Tourism Research, 33(1), 87-108. https://doi.org/10.1016/j.annals.2005.04.004

Plummer, R., Kulczycki, C., \& Stacey, C. (2006). How are we working together? A framework to assess collaborative arrangements in tourism. Current Issues in Tourism, 9(6), 499-515. https://doi.org/10.2167/cit284.0

Pramono, W.T., Anggriani, S.D., Meiji, N.H.P., Ujang, N., \& Sayono, J. (2021). Awakening Local Tourism Based on Indische Architecture in Indonesia: Case Study Kajoetangan Kampong Heritage of Malang. GeoJournal of Tourism and Geosites, 35(2), $437-$ 444. https://doi.org/10.30892/gtg.35223-670

Prayag, G., Hosany, S., \& Odeh, K. (2013). The role of tourists' emotional experiences and satisfaction in understanding behavioral intentions. Journal of Destination Marketing \& Management, 2(2), 118-127. https://doi.org/10.1016/j.jdmm.2013.05.001

Ramukumba, T. (2019). Community views on the role of tourism in local development: a South African study. GeoJournal of Tourism and Geosites, 25(2), 638-647. https://doi.org/10.30892/gtg.25228-386

Rogerson, C.M., \& Rogerson, J.M. (2019). Tourism, local economic development and inclusion: evidence from Overstrand Local Municipality, South Africa. GeoJournal of Tourism and Geosites, 25(2), 293-308. https://doi.org/10.30892/gtg.25202-360

Romshoo, S.A., \& Rashid, I. (2012). Assessing the impacts of changing land cover and climate on Hokersar wetland in Indian Himalayas. Arabian Journal of Geosciences, 7(1), 143-160. https://doi.org/10.1007/s12517-012-0761-9

Ross, S., \& Wall, G. (1999). Ecotourism: Towards congruence between theory and practice. Tourism Management, 20(1), $123-132$. https://doi.org/10.1016/S0261-5177(98)00098-3

Saito, H., \& Ruhanen, L. (2017). Power in tourism stakeholder collaborations: Power types and power holders. Journal of Hospitality and Tourism Management, 31, 189-196. https://doi.org/10.1016/j.jhtm.2017.01.001

Scheyvens, R. (2011). The challenge of sustainable tourism development in the Maldives: Understanding the social and political dimensions of sustainability. Asia Pacific Viewpoint, 52(2), 148-164. https://doi.org/10.1111/j.1467-8373.2011.01447.x

Serravalle, F., Ferraris, A., Vrontis, D., Thrassou, A., \& Christofi, M. (2019). Augmented reality in the tourism industry: A multistakeholder analysis of museums. Tourism Management Perspectives, 32, 100549. https://doi.org/10.1016/j.tmp.2019.07.002

Sofield, T. (2003). Empowerment for sustainable tourism development. Amsterdam: Pergamon.

Su, L., Huang, S.S., \& Pearce, J. (2018). How does destination social responsibility contribute to environmentally responsible behaviour? A destination resident perspective. Journal of Business Research, 86, 179-189. https://doi.org/10.1016/j.jbusres.2018.02.011

Su, L., \& Swanson, S.R. (2017). The effect of destination social responsibility on tourist environmentally responsible behavior: Compared analysis of first-time and repeat tourists. Tourism Management, 60, 308-321. https://doi.org/10.1016/j.tourman.2016.12.011

Siakwah, P., Musavengane, R., \& Leonard, L. (2019). Tourism Governance and Attainment of the Sustainable Development Goals in Africa. Tourism Planning \& Development, 1-29. https://doi.org/10.1080/21568316.2019.1600160

Telfer, D.J., \& Sharpley, R. (2015). Tourism and Development in the Developing World (2nd ed.). Routledge.

Theodoulidis, B., Diaz, D., Crotto, F., \& Rancati, E. (2017). Exploring corporate social responsibility and financial performance through stakeholder theory in the tourism industries. Tourism Management, 62, 173-188. https://doi.org/10.1016/j.tourman.2017.03.018

Tkaczynski, A., Rundle-Thiele, S.R., \& Beaumont, N. (2009). Segmentation: A tourism stakeholder view. Tourism Management, 30(2), 169-175. https://doi.org/10.1016/j.tourman.2008.05.010

Vargas-Sánchez, A., Plaza-Mejia, M.D.L.Á., \& Porras-Bueno, N. (2009). Understanding residents' attitudes toward the development of industrial tourism in a former mining community. Journal of Travel Research, 47(3), 373-387. https://doi.org/10.1177/0047287508322783

Vargas-Sanchez, A., Porras-Bueno, N., \& de los Ángeles Plaza-Mejía, M. (2011). Explaining residents' attitudes to tourism: Is a universal model possible?. Annals of tourism research, 38(2), 460-480. https://doi.org/10.1016/j.annals.2010.10.004

Veal, A.J. (2002). Leisure and Tourism Policy and Planning. Second Edition. CABI Publishing. UK

Waligo, V.M., Clarke, J., \& Hawkins, R. (2013). Implementing sustainable tourism: A multi-stakeholder involvement management framework. Tourism management, 36, 342-353. https://doi.org/10.1016/j.tourman.2012.10.008

Wang, Y., \& Bramwell, B. (2012). Heritage protection and tourism development priorities in Hangzhou, China: A political economy and governance perspective. Tourism Management, 33(4), 988-998. https://doi.org/10.1016/j.tourman.2011.10.010

Ward, C., \& Berno, T. (2011). Beyond social exchange theory. Annals of Tourism Research, 38(4), 1556-1569. https://doi.org/10. 1016/j.annals.2011.02.005

Weaver, D.B., \& Lawton, L.J. (2013). Resident perceptions of a contentious tourism event. Tourism Management, 37, 165-175. https://doi.org/10. 1016/j.tourman.2013.01.017

Wilopo, Iqbal, M., Alfisyahr, R., \& Irawan, A. 2020. Strategic issues of tourism destination in Indonesia: Are the market ready? International Journal of Entrepreneurship, 24(2), 1-16.

Wondirad, A., Tolkach, D., \& King, B. (2020). Stakeholder collaboration as a major factor for sustainable ecotourism development in developing countries. Tourism Management, 78, 104024. https://doi.org/10.1016/j.tourman.2019.104024

Woosnam, K.M. (2010). Comparing Residents' and Tourists' Emotional Solidarity with One Another. Journal of Travel Research, 50(6), 615-626. https://doi.org/10.1177/0047287510382299

Xuchao, W., Priyadarsini, R., \& Eang, L.S. (2010). Benchmarking energy use and greenhouse gas emissions in Singapore's hotel industry. Energy policy, 38(8), 4520-4527. https://doi.org/10.1016/j.enpol.2010.04.006

Yoon, Y., Gursoy, D., \& Chen, J.S. (2001). Validating a tourism development theory with structural equation modeling. Tourism Management, 22(4), 363-372. https://doi.org/10.1016/S0261-5177(00)00062-5

Zhang, K., Chen, Y., \& Li, C. (2019). Discovering the tourists' behaviors and perceptions in a tourism destination by analyzing photos' visual content with a computer deep learning model: The case of Beijing. Tourism Management, 75, 595-608. https://doi.org/10.1016/j.tourman.2019.07.002

Zhang, L., \& Gao, J. (2016). Exploring the effects of international tourism on China's economic growth, energy consumption and environmental pollution: Evidence from a regional panel analysis. Renewable and Sustainable Energy Reviews, 53, $225-234$. https://doi.org/10.1016/j.rser.2015.08.040

Zeng, J., Wen, Y., Bi, C., \& Feiock, R. (2021). Effect of tourism development on urban air pollution in China: The moderating role of tourism infrastructure. Journal of Cleaner Production, 280, 124397. https://doi.org/10.1016/j.jclepro.2020.124397 